\title{
Trichoderma citrinoviride: A Potent Biopriming Agent for the Alleviation of Salt Stress in Maize
}

\author{
Trichoderma citrinoviride: Mısırda Tuz Stresinin Azaltılmasında \\ Kullanılabilecek Potansiyel Bir Ön Muamele Ajanı
}

Research Article

Abdullah M. Yesilyurt*, Necla Pehlivan*, Nuran Durmus, Sengul A. Karaoglu

Department of Biology, Faculty of Arts and Sciences, Recep Tayyip Erdogan University, Rize, Turkey.

\section{A B S TR ACT}

$\mathrm{T}$

he rapid increase in global population and industrial pollution pose severe environmental threats to agriculture that are exacerbated by salt stress. Molecular characterization of new fungal isolates and assessment of their impact on agriculture might be an eco-friendly approach to modulating salt tolerance. Herein, fungal seed biopriming was conducted on salt $(\mathrm{NaCl})$ stressed maize in a dose-dependent manner. Genetic lineages of fungi were identified using well-known fungal ITS (internal transcribed spacer) barcodes that revealed similarity to the Trichoderma citrinoviride (T11C) species. Fv/Fm, ETR and qP were recorded as close to optimum in bioprimed maize plants after application of salt stress. NPQ (nonphotochemical quenching) decreased slightly in respective groups. Higher photosynthetic pigment contents were also detected. T11C seed biopriming decreased the lipid oxidation remarkably under salt stress. SOD, GPX, GR and CAT activities were not found to be significantly induced in the roots or leaves of T11C after biopriming. However, higher RWC (relative water content), soluble protein and proline were measured in bioprimed test groups treated with high salt stress, demonstrating increased osmoregulatory capacity. Our ongoing research is directed toward developing powdered fungal biopreperations to assay multiple stress tolerances in agriculture for agroeconomically important cereals such as maize.

\section{Key Words}

Trichoderma citrinoviride, seed biopriming, maize, chloropyhll fluorescence.

\section{öz}

\begin{abstract}
üresel nüfus artışı ve endüstriyel kirlilik, tuz stresi ile birleştiğinde, tarımsal şartları ağırlaştıran çevresel tehditlere dönüşmektedir. Yeni fungal izolatların moleküler karakterizasyonu ve bunların tarım üzerindeki etkilerinin araştırılması, tuz stresi toleransının kontrolünde çevre dostu bir yaklaşım olabilir. Bu bağlamda mevcut çalışmada, doza bağımlı tuz ( $\mathrm{NaCl}$ ) stresi uygulanan mısır tohumlarına fungal ön muamele gerçekleştirilmiştir. Fungusun genetik bağlantıları iyi bilinen ITS barkodları kullanılarak tanımlanmış ve Trichoderma citrinoviride (T11C) türüne benzerlik gösterdiği ortaya çıkarılmıştır. Fungal uygulamanın yapıldığı stres altındaki mısır bitkilerinde, maksimum kuantum verimi (Fv/Fm), elektron transfer oranı (ETO), ve fotokimyasal kullanılmanın (qP) optimuma yakın olduğu, bununla birlikte NPQ (fotokimyasal olmayan floresans sönmesi) değerlerinin ise; ilgili gruplarda azaldığı belirlenmiştir. Ayrıca, fotosentetik pigment içeriklerinin yüksek olduğu kaydedilmiştir. T11C fungal muamelesinin, tuz stresi altındaki bitkilerde lipid oksidasyonunu düşürdüğü tespit edilmekle birlikte, mısır kök ve yapraklarında SOD, GPX, GR ve CAT aktivitelerini belirgin şekilde arttırmadığı gözlenmiştir. Yüksek tuz stresi uygulanan test gruplarında, yüksek RWC (göreceli su içeriği), çözünebilir protein ve prolinin tespiti, fungal ön muamelenin, bitkilerde artan bir osmoregülasyon kapasitesini tetiklediğini kanıtlamıştır. Devam eden çalışmalar, mısır gibi ekonomik açıdan önemli tahıllarda çoklu stres toleranslarını test etmek adına, tarımsal uygulamalarda kullanılabilecek toz halindeki mantar biyopreparatlarının geliştirilmesine yöneliktir.
\end{abstract}

\section{Anahtar Kelimeler}

Trichoderma citrinoviride, tohum ön muamelesi, mısır, klorofil floresans.

Article History: Received: Sep 10, 2017; Revised: Nov 22, 2017; Accepted: Dec 06, 2017; Available Online: Feb $20,2018$.

DOI: 10.15671/HJBC.2018.218

Correspondence to: A.M. Yeşilyurt and N. Pehlivan, Department of Biology, Recep Tayyip Erdogan University, Rize, Turkey. 


\section{INTRODUCTION}

alt stress is one of the most important $S$ agricultural threats expected to impact crop yields in the near future due to intensive irrigation, chemical contamination from inorganic fertilizers and destruction of natural vegetation lands on earth [1]. These effects are expected to become increasingly catastrophic in agriculture considering the compounding threat of severe climate fluctuations and increased air pollution across the globe. Consequently, crop yields may decline and jeopardize our food security. Hence it is necessary to take precautions that can reduce plant stresses and stave off damages to the environment.

Maize is a crucial cereal for the agricultural provisions required by mankind. Maize is employed in a wide range of applications including clothing, food and alternative fuels [2]. Aside from a few exception genetic variants [3], maize is a salt-sensitive plant with significant reduction in crop yield following salt stress. Thus, genetic modifications that bolster salt tolerance may improve yields in maize.

Though maize does recruit various mechanisms to combat salt stress, even moderately elevated soil salt content can debilitate growth. Accordingly, crop yield may improve with incorporation of externally derived stress relief agents during key growth phases [4]. Chemical priming is one approach to increasing stress tolerance that entails exposing the plant to periodically increasing chemical stressors over a prolonged time frame to safely activate endogenous defense mechanisms. However, the chemicals used for plant priming are mostly synthetic chemicals (reactive oxygen, nitrogen, sulfur species (RONSS) [5] or fungicides (pyrabactin) [6] and have potential to be toxic to the environment and consumers throughout the food web. Natural agents/metabolites may be used as an eco-friendly approach. Fungal genus Trichoderma may serve as a viable candidate and is the focus of this study. Trichoderma are endophytic plant symbionts that are commonly used for the biological control of various plant pathogens via chemotropic and mycoparasitic interactions [7]. Some Trichoderma strains can interact with roots for disease resistance and abiotic stress tolerance consequently improving plant growth and development under unfavorable environmental conditions [8]. However, since different genetic backgrounds of this genus might exert variable potency to eliminate stress-related injuries in the plant cell, molecular identification of new fungal isolates can be important for agricultural preparate purposes as organic stress-relieving fertilizers. Additionally, since the photosynthetic efficiency of salt-stressed maize after Trichoderma biopriming is unknown in the literature, our approach is to modulate the salt stress response using our own isolate, T11C, to mitigate salt stress in before maize seeds reach germination.

\section{MATERIALS and METHODS}

\section{Isolation and Molecular Identification of Target Fungal Strain}

Microfungus used in this study were isolated from the soil of tea gardens in Rize-iyidere of Turkey $\left(41^{\circ} 0.731^{\prime} \mathrm{N}, 40^{\circ} 21.649^{\prime} \mathrm{E}\right)$ [9] and stored in the Culture Collection Unit of the Microbiology subdivision at Recep Tayyip Erdogan University, Turkey. Annual precipitation in this area exceeds $2400 \mathrm{~mm}$ annually and is classified as a humid, subtropical climate. After phenotypic identification, the isolate was further verified by molecular characterization via a 700 base pair polymerase chain reaction using fragment amplification of the $5.8 \mathrm{~S}$ rDNA gene (using oligonucleotides 5'-ATG AGT ATT CAA CAT TTC CG -3' and 5'-CCA ATG CTT AAT CAG TGA GG-3') of ITS- 1 and ITS- 2 regions.

\section{Revival of the Culture and Preparation of Fungus Inoculum}

The target microfungus was derived from the cultures grown on petri dishes containing Potato Dextrose Agar (Merck, Germany) incubated at $25^{\circ} \mathrm{C}$ for 14 days. Hyphae and spores acquired from pure culture were then transferred into flasks filled with broth media (Malt Extract) and were positioned in a rotary shaker (GFL, Germany) at $27^{\circ} \mathrm{C}$ for 12 days. Filtration was performed to obtain mycelia which were washed with sterile $\mathrm{H}_{2} \mathrm{O}$ and placed in liquid nitrogen. Conidial densities in the spore suspension were 
recorded by a Neubauer slide under a basic light microscope (Olympus BX41, USA). The method of Goettel and Inglis [10] was used to set the density of inoculum up to $1 \times 10^{7}$ conidia $/ \mathrm{mL}$.

\section{Preparation of Fungus Suspension}

T11C fungal inoculum was mixed with $2 \%$ carboxymethyl cellulose and 1\% Tween 20 to achieve adhesion and homogeneity, respectively. Then, Zea mays L. cv. Samada 07 seeds were subjected to a volume of $1 \times 10^{7}$ conidia/mL suspension. Control seeds were soaked in equal volume of sterile distilled water. Incubation was performed for one hour after 30 min seed sterilization with $1 \%$ bleach solution $(\mathrm{NaClO})$ and rinsed thoroughly in distilled water.

\section{Salt Stress Applications}

The applications were organized into a randomized block design. Six seeds for each treatment were placed into plastic pots (12 by 12 by $5 \mathrm{~cm}$ ) and incubated at $25 \pm 1^{\circ} \mathrm{C}$ with $16 \mathrm{~h}$ of light with $70 \%$ relative humidity and $350 \mu \mathrm{mol} \mathrm{m}^{-2} \mathrm{~s}^{-1}$ light intensity period in a growth chamber. Soil used for planting was autoclaved in polyethylene bags two times before used. Six different groups were used to conduct salt stress experiments: non-bioprimed control seeds watered with pure $\mathrm{H}_{2} \mathrm{O}$ (control); $50 \mathrm{mM} \mathrm{NaCl}$; or $100 \mathrm{mM} \mathrm{NaCl}$; and seeds bioprimed with the isolated $\mathrm{T} 11 \mathrm{C}$ strain and no salt treated (T11C), bioprimed with $\mathrm{T} 11 \mathrm{C}$ at first, thereafter subjected to the $50 \mathrm{mM} \mathrm{NaCl}(50 \mathrm{mM}$ $+\mathrm{T} 11 \mathrm{C})$ and $100 \mathrm{mM} \mathrm{NaCl}(100 \mathrm{mM}+\mathrm{T} 11 \mathrm{C})$. The efficacy of T11C inoculum on the growth of maize seedlings was evaluated after 2 weeks following seed planting. $50 \mathrm{mM}$ and $100 \mathrm{mM} \mathrm{NaCl}$ were exposed to the seedlings every two days for 10 days. Controls were watered with pure $\mathrm{H}_{2} \mathrm{O}$. In case of nutrient deficiency, Hoagland solution was applied every 5 days from sowing to harvested day. Maize seedlings from each treatment were gently separated from the pots and phenotypic and biochemical analyses were conducted. Growth Measurements

Planting mix of the maize seedlings of each treatment were gently removed from the root system. Roots and shoots were dried at $70^{\circ} \mathrm{C}$ for 72 hours to record dry weight (DW) values. Root fresh weight (FW) and DW of maize seedlings besides respective lengths were recorded. Turgid weights of $0.5 \mathrm{~g}$ leaf samples were noted after soaking in distilled $\mathrm{H}_{2} \mathrm{O}$ in the dark at $4^{\circ} \mathrm{C}$ for $16 \mathrm{~h}$ to measure the RWC [11].

\section{Analysis of Biochemical Compounds}

Following plant salt stress, response parameters were determined in the second fully developed apical leaves of each test plant based on the cited references: concentration of photosynthetic pigments (total chlorophyll (Chl) and carotenoid (Car)) [12,13], and malondialdehyde (MDA) expressed as nmol MDA per $\mathrm{g} F \mathrm{~F}$ ) which is the end-product of lipid oxidation [14] and proline accumulation was given as $\mathrm{mg}$ proline per $\mathrm{g} \mathrm{FW}$ in the presented figures [15].

\section{Antioxidant Enzyme activities}

Antioxidant enzymes, such as superoxide dismutase (SOD, EC 1.15.1.1), guaiacol peroxidase (GPX, EC 1.11.1.7), catalase (CAT, EC 1.11.1.6) and glutathione reductase (GR, EC 1.6.4.2) were determined spectrophotometrically by using the methods of Dhindsa and Matowe [16], Urbanek et al. [17], Aebi [18] and Foyer and Halliwell [19], respectively. Enzyme extractions for the activity assays were conducted in potassium phosphate $\left(\mathrm{K}_{2} \mathrm{HPO}_{4}\right)$ buffer $(50 \mathrm{mM}, \mathrm{pH}$ 7.0) prepared with $1 \mathrm{mM}$ EDTA and 1\% polyvinylpolypyrrolidone. Bovine serum albumin was used for soluble protein measurements [20].

\section{Chlorophyll Fluorescence Measurements}

The measurements were conducted after day 10 of salt stress exposure. The chlorophyll fluorescence parameters which were recorded by OS5P modulated fluorometer (Opti-Sciences, Hudson, $\mathrm{NH}$, USA) measured in second fully developed apical leaf. The maximum quantum efficiency of PSII readings ( $\mathrm{FV} / \mathrm{Fm}$ (maximal efficiency of PSII photochemistry); $F v=F m-F O$ of dark adapted leaves were collected with dark leaf clip after a short 20 min dark-acclimation period. Fm (maximum) and FO (minimum) yields of the fluorescence of an illuminated leaf obtained based on the method of saturation pulse. The quantum yield of PSII photochemistry (ФPSII) data was acquired by a steady state light adapted yield protocol that yields the ratio between the light amount absorbed in the photochemistry of PSII and the light absorbed by chlorophyll pigments of PSII. Nonphotochemical (NPQ) and photochemical 
quenching $(\mathrm{Pq})$ besides the electron transport rate (ETR) were documented using the Quenching protocol with a PAR clip apparatus. All mentioned parameters were calculated by Fluorometer software itself.

\section{Statistical Analysis}

All tests were performed in triplicate with at least three technical and three biological replicates per treatment. Analysis of variance (ANOVA) with post-hoc Tukey's range test was used to compare averages between different groups. Statistical significance was set to a level of $5 \%(P<0.05)$ [21]. Statistical analyses were performed using the SigmaPlot 12 software (Systat Software Inc. Chicago, USA).

\section{RESULTS}

\section{Identification of Trichoderma citrinoviride Strain 11C}

Amplified DNA sequences of fungus were subjected to the ClustalW multiple sequence alignment in BioEdit. Dendrogram created by neighbor-joining analysis showed that the fungal strain is phylogenetically linked to the Trichoderma citrinoviride T200 with $99 \%$ sequence similarity (NCBI GenBank: HQ596983.1) from now on, we have labeled the inoculant as T11C for further physiological tests (unpublished data).

\section{T11C Seed Biopriming Improves Phenotypic Growth Traits Under Dose Dependent $\mathrm{NaCl}$ Stress}

We have analyzed if T11C biopriming have potential to provide increased tolerance in dose dependent $\mathrm{NaCl}$ stressed maize plants. The tolerance capacity/performance of the plants from each treatment (control (C), the $50 \mathrm{mM}$ $\mathrm{NaCl}, 100 \mathrm{mM} \mathrm{NaCl}, \mathrm{T} 11 \mathrm{C}$ only treated and $50 \mathrm{mM}$ and $100 \mathrm{mM} \mathrm{NaCl}$ stressed plus T11C treated (50 $\mathrm{mM}+\mathrm{T} 11 \mathrm{C}$ and $100 \mathrm{mM}+\mathrm{T} 11 \mathrm{C}$ respectively) were evaluated (Figure 1). At $50 \mathrm{mM}$ and $100 \mathrm{mM} \mathrm{NaCl}$ concentrations, both root and shoot lengths displayed reductions in comparison to the wellwatered control plants (Figure 1A). T11C seed biopriming improved both root and shoot growth of $50 \mathrm{mM}$ and $100 \mathrm{mM} \mathrm{NaCl}$ stressed plants (50 $\mathrm{mM}+\mathrm{T} 11 \mathrm{C}$ and $100 \mathrm{mM}+\mathrm{T} 11 \mathrm{C})$ in comparison with
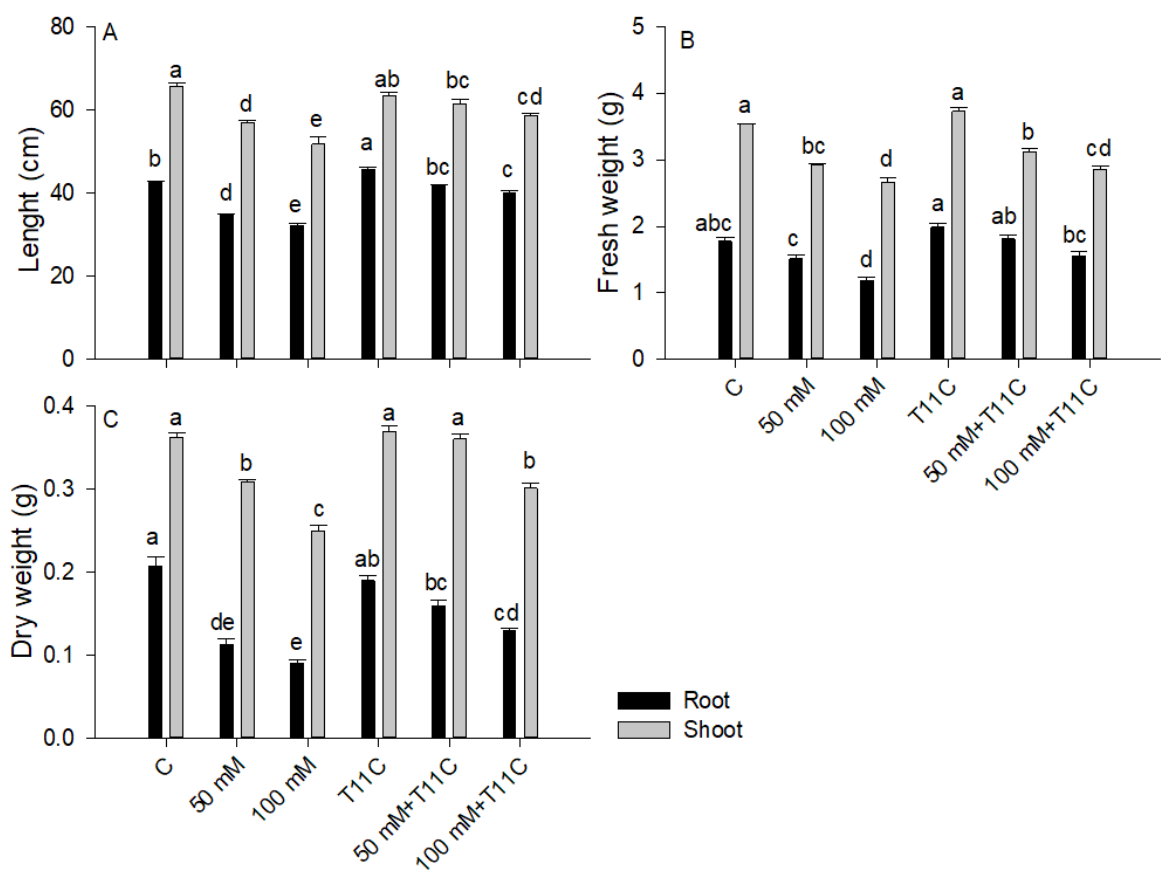

Figure 1. The impact of seed biopriming of Trichoderma citrinoviride strain $11 \mathrm{C}$ on $(A)$ growth and $(B, C)$ biomass yield of maize plants under different salt concentrations for ten days. The plants were organized into 6 treatments: well-watered only (C), exposed to 50 and $100 \mathrm{mM} \mathrm{NaCl}$ only (50 mM, $100 \mathrm{mM}$ ), seed bioprimed with T11C and well-watered (T11C), seed bioprimed with T11C and $50 \mathrm{mM} \mathrm{NaCl}$ stressed (50mM + T11C), seed bioprimed with T11C and $100 \mathrm{mM} \mathrm{NaCl}$ stressed (100 mM + T11C). Error bars indicate standard deviation and different letters (a, b, $c, d, e, f)$ represent significant difference (ANOVA, $p<0.05)$ among the different treatments $(n=3)$. 
the non-bioprimed $50 \mathrm{mM}$ and $100 \mathrm{mM} \mathrm{NaCl}$ plant groups by $20.67 \%$ and $24.06 \%$ and $7.89 \%$ and $13.52 \%$ respectively (Figure $1 \mathrm{~A}$ ).

Conversely, remarkable differences were detected in fresh and dry weights of roots and shoots upon either salt treatment or priming. The reductions in root fresh and dry weights were found to be at least $14 \%$ and $45 \%$, respectively, under salt stress compared to with weights of well-watered control plants. When salt concentration was increased to $100 \mathrm{mM}, 100 \mathrm{mM}$ + T11C bioprimed plants showed improved root fresh and dry weight at a increase of $31.69 \%$ and $43.33 \%$, respectively, when compared to the 100 $\mathrm{mM}$ salt stressed only group of plants (Figures $1 \mathrm{~B}$ and $1 \mathrm{C})$.

Additionally, when shoot data was analyzed in terms of fresh and dry weights, seed biopriming displayed similar protective effects, yet with lesser increases by $6.5 \%$ and $19.48 \%$ (for the $50 \mathrm{mM}+\mathrm{T11C}$ group), respectively, besides $7.28 \%$ and $20.48 \%$ (for the $100 \mathrm{mM}+\mathrm{T} 11 \mathrm{C}$ group) respectively, compared to the salt stressed only plants $(50 \mathrm{mM}$ and $100 \mathrm{mM} \mathrm{NaCl}$ only group (Figures 1B and 1C).

\section{T11C Bioprimed Maize Seeds Outperform the Control Plants with Regard to the Water Utilization}

To analyze how seed biopriming of T11C would affect maize plants in terms of water status and pigment concentrations ( $\mathrm{Chl}$ and $\mathrm{Car}$ ) under salinity, different levels of $\mathrm{NaCl}$ concentrations were applied separately. At the end of the experimental period (10 days) the reduction observed in the RWC of the control roots and leaves was significant under salt stress, whereas T11C seed biopriming applied shortly before germination leading to an induction of robust water status of roots and leaves of $50 \mathrm{mM}$ and $100 \mathrm{mM} \mathrm{NaCl}$ stressed plants for each dose of stress by keeping the water rate by $92.36 \%$ and $91.78 \%$ for the roots and $93.29 \%$ and $91.54 \%$ for the leaves for respective treatments (Figure $2 \mathrm{~A}$ ).
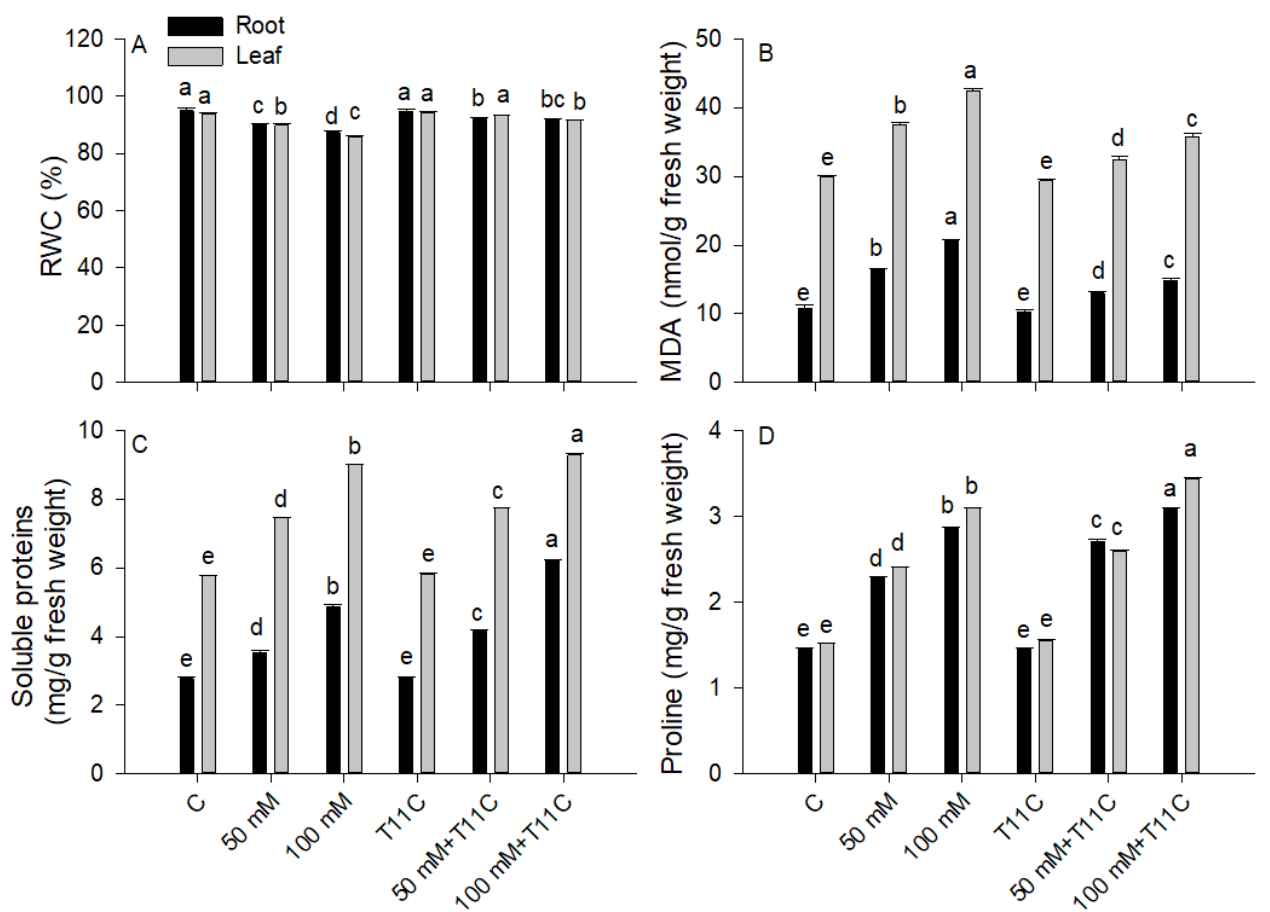

Figure 2. The potency of seed biopriming of Trichoderma citrinoviride strain 11C on relative water (RWC) (A), malondialdehyde (MDA) (B), soluble proteins (C) and proline (D) contents of maize plants under different salt concentrations for ten days. The plants were organized into 6 treatments: well-watered only (C), exposed to 50 and $100 \mathrm{mM} \mathrm{NaCl}$ only $(50 \mathrm{mM}, 100 \mathrm{mM})$, seed bioprimed with T11C and well-watered (T11C), seed bioprimed with T11C and $50 \mathrm{mM} \mathrm{NaCl}$ stressed $(50 \mathrm{mM}+\mathrm{T} 11 \mathrm{C})$, seed bioprimed with T11C and $100 \mathrm{mM} \mathrm{NaCl}$ stressed (100 mM + T11C). Error bars indicate standard deviation and different letters $(a, b, c, d, e, f)$ represent significant difference (ANOVA, $p<0.05)$ among the different treatments $(n=3)$. 

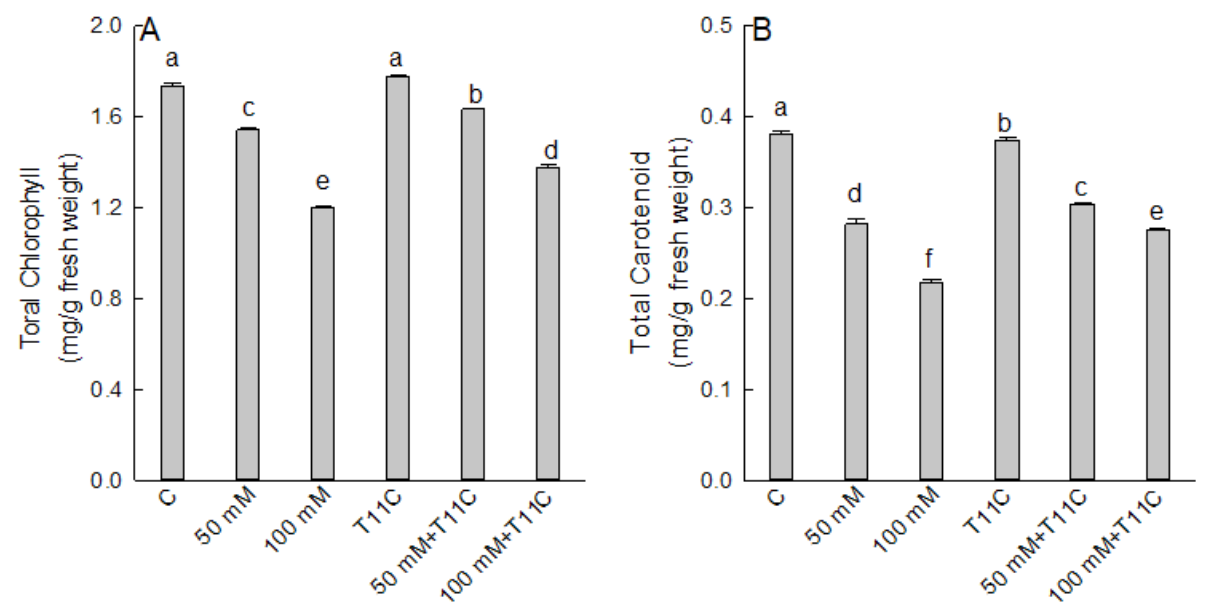

Figure 3. The potency of seed biopriming of Trichoderma citrinoviride strain $11 \mathrm{C}$ on total chlorophyll (A) and carotenoid (B) contents of maize plants under different salt concentrations for 10 days. The plants were organized into 6 treatments: well-watered only (C), exposed to 50 and $100 \mathrm{mM} \mathrm{NaCl}$ only $(50 \mathrm{mM}, 100 \mathrm{mM})$, seed bioprimed with T11C and well-watered (T11C), seed bioprimed with $\mathrm{T} 11 \mathrm{C}$ and $50 \mathrm{mM} \mathrm{NaCl}$ stressed $(50 \mathrm{mM}+\mathrm{T} 11 \mathrm{C})$, seed bioprimed with T11C and $100 \mathrm{mM} \mathrm{NaCl}$ stressed (100 mM + T11C). Error bars indicate standard deviation and different letters $(a, b, c, d, e, f)$ represent significant difference (ANOVA, $p<0.05)$ among the different treatments $(n=3)$.

\section{T11C Bioprimed Maize Seeds Confer}

\section{Healthier Biochemical Characteristics and} Photosynthetic Pigment Content Under either Dose of $\mathrm{NaCl}$ Stress

To document the effect of T11C seed biopriming in maize under different doses of $\mathrm{NaCl}$, relevant biochemical parameters were assayed (Figures 2, 3 and 4). Without $\mathrm{NaCl}$ in the soil mix, no significant difference was observed between well-watered control and T11C treated only control groups. However, high dose of salt led to significant proline accumulation with at least $7 \%$ and $8 \%$ increase in the roots and leaves, respectively, compared to the non-bioprimed but $\mathrm{NaCl}$ only treated group. T11C seed biopriming also remarkably reversed the lipid oxidation percentage in each dose of $\mathrm{NaCl}$ stressed maize roots by decreasing the production of MDA at a rate of $20.47 \%$ and $28.12 \%$ with respect to the $50 \mathrm{mM}$ and $100 \mathrm{mM} \mathrm{NaCl}$ only irrigated plants, respectively. A similar healing effect (at least by $13 \%$ increase) was detected in turn in the leaves of maize with T11C presence (Figure 2B). Soluble protein content, on the other hand, was assayed in the roots and leaves of maize plants and almost $30 \%$ increase was detected in the roots of 100 $\mathrm{mM}+\mathrm{T11C}$ treated plants with regard to the 100 $\mathrm{mM} \mathrm{NaCl}$ treated only ones (Figure $2 \mathrm{C}$ ). We have also detected that proline as an osmoprotectant significantly accumulated in the roots and leaves of the plants irrigated with two different $\mathrm{NaCl}$ concentrations as anticipated (Figure 2D).

On the other hand, total $\mathrm{Chl}$ of the maize plants grouped into $50 \mathrm{mM}+\mathrm{T} 11 \mathrm{C}$ and $100 \mathrm{mM}+$ T11C were found to be represented the identical tendency by $5.99 \%$ and $14.61 \%$ increase rates when compared with $50 \mathrm{mM}$ and $100 \mathrm{mM}$ $\mathrm{NaCl}$ irrigated only plants (Figure $3 \mathrm{~A}$ ). For the concentrations of Car, increase was recorded by $7.79 \%$ and $26.49 \%$ for the respective treatments (Figure 3B).

All antioxidant enzymes were induced gradually both in the roots and leaves of the maize plants under either concentrations of $\mathrm{NaCl}$ stress with regard to the well-watered control (Figure 4). Interestingly the SOD activity markedly decreased by at least $9 \%$ and $21.36 \%$ in the roots and the leaves, respectively, of the T11C bioprimed plants that were irrigated with $100 \mathrm{mM}$ $\mathrm{NaCl}$ (Figure 4A).

However, GPX activity was increased by $14.74 \%$ and $5.78 \%$ in the roots and $5.45 \%$ and $2.36 \%$ in the leaves of $50 \mathrm{mM}+\mathrm{T} 11 \mathrm{C}$ and $100 \mathrm{mM}+$ T11C treated groups, respectively, when compared to the $50 \mathrm{mM}$ and $100 \mathrm{mM} \mathrm{NaCl}$ only treatments 

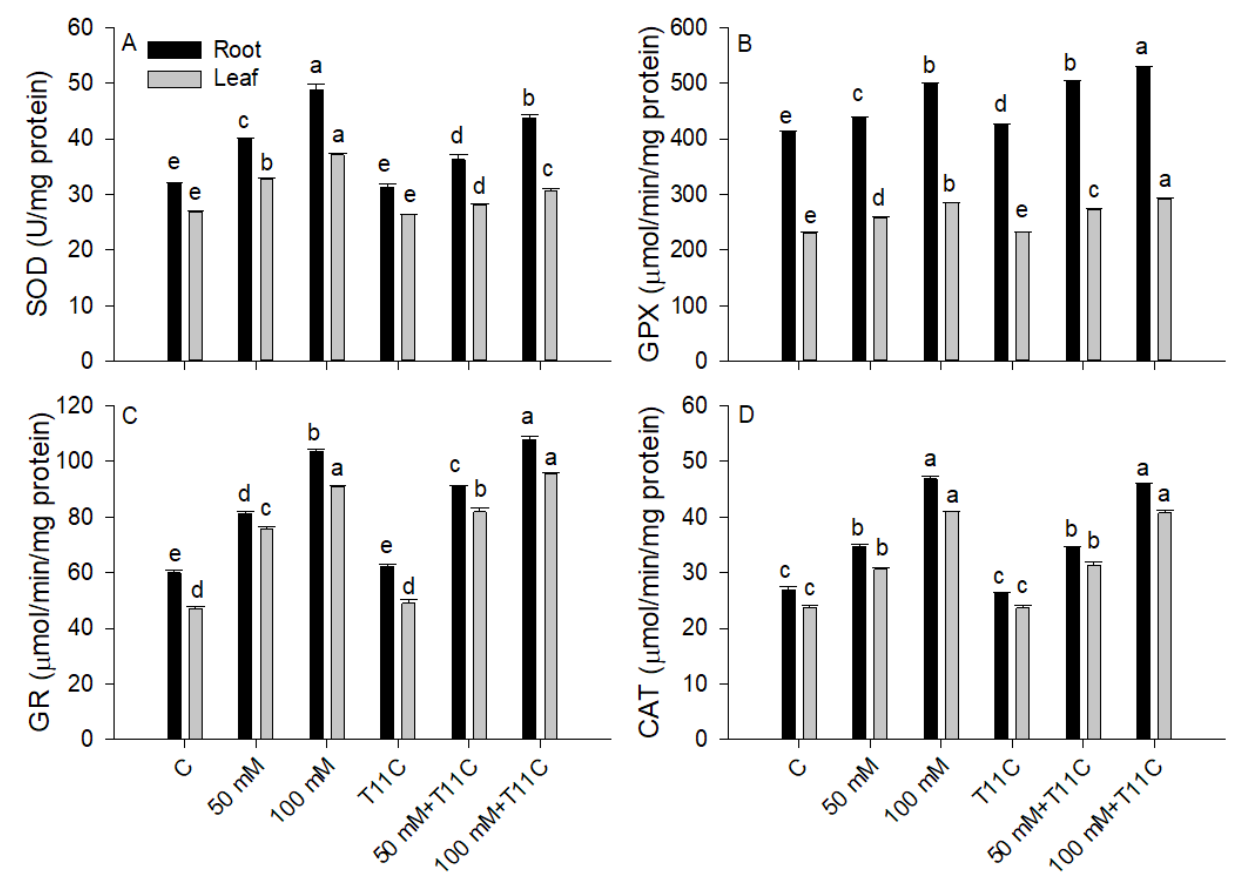

Figure 4. The potency of seed biopriming of Trichoderma citrinoviride strain 11C on SOD (A), GPX (B), GR (C) and CAT (D) activities in maize plants under different salt concentrations for ten days. The plants were organized into 6 treatments: well-watered only (C), exposed to 50 and $100 \mathrm{mM} \mathrm{NaCl}$ only $(50 \mathrm{mM}, 100 \mathrm{mM})$, seed bioprimed with T11C and well-watered (T11C), seed bioprimed with T11C and $50 \mathrm{mM} \mathrm{NaCl}$ stressed (50 mM + T11C), seed bioprimed with T11C and $100 \mathrm{mM} \mathrm{NaCl}$ stressed $(100 \mathrm{mM}+\mathrm{T11C})$. Error bars indicate standard deviation and different letters $(a, b, c, d, e, f)$ represent significant difference (ANOVA, $p<0.05)$ among the different treatments $(n=3)$.

(Figure 4B). Accordingly, when we analyzed the GR data, the increase was $12 \%$ and $4.28 \%$ for the roots and $7.96 \%$ and $5 \%$ for the leaves of the 50 $\mathrm{mM}+\mathrm{T} 11 \mathrm{C}$ and $100 \mathrm{mM}+\mathrm{T} 11 \mathrm{C}$ group of plants in comparison with the above mentioned respective groups of treatments (Figure $4 \mathrm{C}$ ). However, no significant difference was detected in the CAT activity either in the roots or leaves of the plants inoculated with $50 \mathrm{mM}+\mathrm{T} 11 \mathrm{C}$ and $100 \mathrm{mM}+\mathrm{T} 11 \mathrm{C}$ treatments compared with respective $\mathrm{NaCl}$ only groups (Figure 4D).

\section{T11C Bioprimed Maize Seeds Display Improved Chlorophyll Fluorescence}

The efficiency measured as Fv/Fm was decreased relative to the control plants after 10 days of salt stress under each concentration of salt (50 $\mathrm{mM}$ and $100 \mathrm{mM} \mathrm{NaCl}$ ) (Figure 5). Reductions were observed in Fv/Fm, ETR, qP and $\Phi P S I I$ by each dose of salt concentration whereas, NPQ values were slightly increased depending on $\mathrm{NaCl}$ dosage (Figure 5A, B, C, D and E). Subsequently, T11C biopriming apparently elevated the efficacy of the photosynthetic apparatus in maize plants.
Data reported improvements by $4.41 \%$ in $\mathrm{Fv} /$ $\mathrm{Fm}, 3.01 \%$ in ФPSII, $10.61 \%$ in ETR and $4.73 \%$ in qP. In addition, a decline by $16.38 \%$ in NPQ was detected in $100 \mathrm{mM}+$ T11C treatments with regard to the $100 \mathrm{mM} \mathrm{NaCl}$ treatment only (Figure 5).

\section{DISCUSSION}

Salts are essential criteria for robust soil characteristics. However, excessive amounts of salt in the soil, especially $\mathrm{NaCl}$ (table salt), induce changes in the genetic expressions of plants that limit their productivity, causing yield penalties and death [22]. The degree of growth impairment might vary based on salt dose and the plant's genetic composition. However, glycophytes are particularly susceptible to stress under high concentrations of salt [3].

One of the most important crops for food security is maize but most strains are glycophytes, excluding the few salt tolerant varieties resulting from polymorphisms during evolution or natural cross-pollination [3]. Maize has a wide range of applications, from our clothing to our food. It 

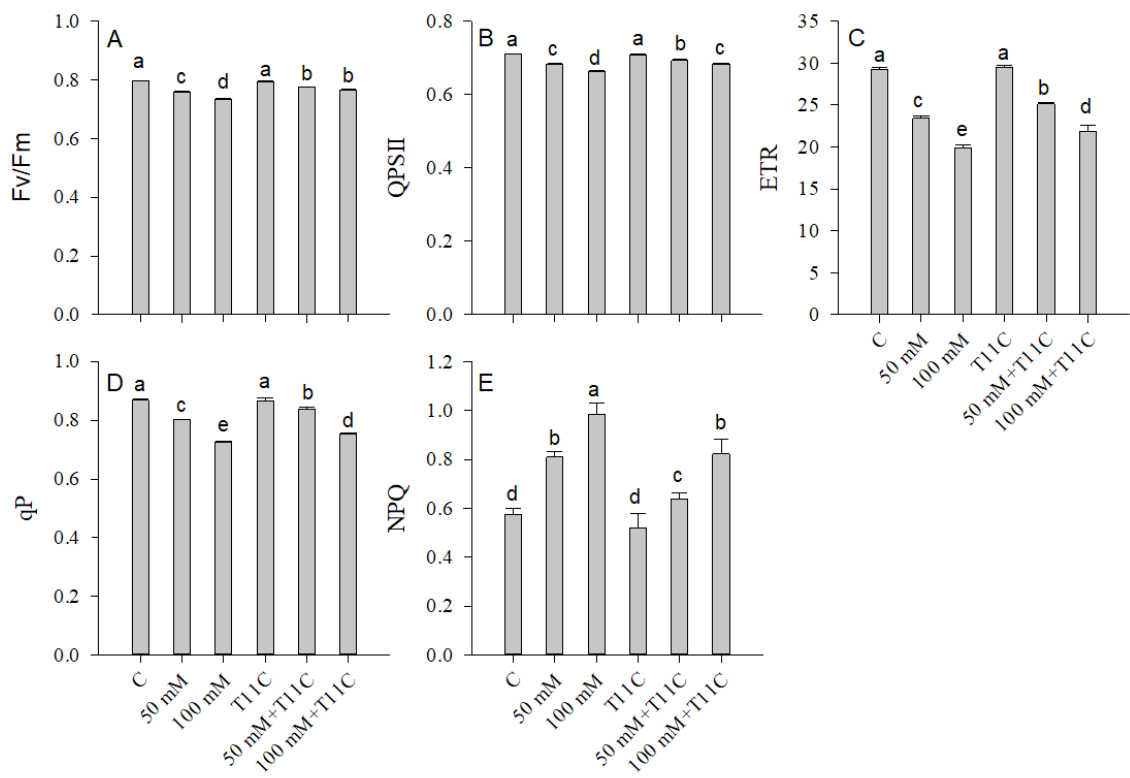

Figure 5. The impact of seed biopriming of Trichoderma citrinoviride strain $11 \mathrm{C}$ on chlorophyll fluorescence parameters $(A, B, C, D$ and $E$ ) of maize plants under different salt concentrations for ten days. The plants were organized into 6 treatments: well-watered only (C), exposed to 50 and $100 \mathrm{mM} \mathrm{NaCl}$ only $(50 \mathrm{mM}, 100 \mathrm{mM})$, seed bioprimed with T11C and well-watered (T11C), seed bioprimed with $\mathrm{T} 11 \mathrm{C}$ and $50 \mathrm{mM} \mathrm{NaCl}$ stressed $(50 \mathrm{mM}+\mathrm{T} 11 \mathrm{C})$, seed bioprimed with T11C and $100 \mathrm{mM} \mathrm{NaCl}$ stressed (100 mM + T11C). Error bars indicate standard deviation and different letters $(a, b, c, d, e, f)$ represent significant difference (ANOVA, $p<0.05$ ) among the different treatments $(n=3)$.

is also an important source of alternative fuels and raw dextrin derived from processed starch. Using maize in thousands of processed products demonstrates its agro-economic importance [2]. Given that most strains of maize are glycophytic, even moderate concentrations of salt are sufficient to impair yields. Additionally, global climate change is worsening secondary stresses that decrease salt tolerance. Therefore, food security is becoming increasingly compromised. Securing agricultural productivity in a safe manner is ultimately a must. The problem demands eco-friendly approaches that do not exert additional stress on the environment. The current chemical solutions are problematic for human health and accrue large costs, in addition to harming the beneficial microbial flora in the soil [23]. In this context, Trichoderma genus poses heightened suitability. Instead of using chemical solutions, molecular identification of new families of microorganisms that possess the capacity for stress relief might provide safe, organic and affordable stress control.
The Trichoderma genus, in addition to Bacillus, Azotobacter and Rhizobium, are important as biotic stress-fighting agents and microbial fertilizers [24,25]. Harman and Kubicek [24] also show that the yield quality in the field can be increased by $300 \%$ after the addition of Trichoderma hamatum or Trichoderma koningii. Trichoderma is therefore not only a good biocontrol agent, but also triggers fertility. Furthermore, some species have been shown to produce effective antibiotics, but should be used for biocontrol purposes carefully [26]. Although they are used in biopesticide and organic bio-fertilizer production in agriculture due to their beneficial properties, we have not come across any other data showing the improvement of photosynthetic efficiency for $\mathrm{NaCl}$ tolerance (when Trichoderma is exposed in advance as a seed biopriming agent). The main goal of the present study was to investigate the biopriming capability of T11C characterized from the soil of tea plants around Rize located in the southeastern Black Sea region in Turkey. Since a well-known factor that has a negative impact on plants under salinity conditions is the accumulation of reactive oxygen species (ROS), 
we have tested whether T11C has the ability to reduce damages resulting from accumulation of ROS by inducing antioxidant defense in maize seedlings during dose dependent $(50 \mathrm{mM}$ and 100 mM) $\mathrm{NaCl}$ stress.

Trichoderma biocontrol strains have mechanisms to enhance plant root development [27]. The rhizosphere being changed by the genus provides a set of benefits to the plant by supporting ventilation in the plant root system [24]. Our results supported this notion and we have found outperforming root and shoot lengths as well as root and shoot fresh/dry biomasses in T11C bioprimed plants under salt stress as compared with the plants treated with $\mathrm{NaCl}$ only. Even under well-watered conditions T11C biopriming led to better performance than that of the well-watered only group of plants. Interestingly, when low dose salt $(50 \mathrm{mM})$ exists in the soil, T11C biopriming provided better root fresh weight than that of the well-watered control.

Reduced accumulation of MDA in seed bioprimed group of maize plants was compatible with the above mentioned phenomenon and showed a significant decrease compared to salt only groups after ten days of stress under each dose of $\mathrm{NaCl}$. These findings demonstrate that the oxidation of lipids (reflecting membrane injury) was ameliorated to some extent both in roots and leaves of maize plants bioprimed with T11C, after subjected to varying salt concentrations. Detected pattern in terms of MDA amount was similar between the roots and leaves (Figure 2B). This data is consistent with the hypothesis that T11C exerts a healing effect following $\mathrm{NaCl}-$ induced oxidative injury.

Based on our data corroborating that T11C affects the germination of plants by utilizing the positive effect on growth and promoting fertility, greenness, photosynthesis activity, and $\mathrm{CO}_{2}$ uptake, T11C seed biopriming might be attributable to the improvement in the rate of photosynthesis by controlling the three parameters discussed previously. Apart from that, because of its very effective enzyme systems, Trichodermas are also widely used in other applications such as textiles, food and paper [28]. These enzyme activities help plants increase water-use efficiency particularly due to its capability in the growth of roots and water-extracting and/or holding capacity of plant cells $[25,27]$. Another hypothesized impact of Trichoderma spp. on plants is the solubilisation of some insoluble or semi-soluble minerals by acidifying the soil environment. This subsequently leads to more efficient nutrient availability and/ or uptake besides an increase in the chelation capability of some metals (iron particularly) for the plants by siderophores [29]. In accordance with that, we have found that T11C bioprimed maize plants perform better in terms of RWC under both concentrations of salt in either roots or leaves (Figure 2A).

We first have found a considerable decline in $\mathrm{Chl}$ and $\mathrm{Car}$ content under higher doses of $\mathrm{NaCl}$ stress (100 mM) as anticipated. However, an hour of T11C seed biopriming in advance of the germination phase was found to improve plant photosynthetic efficiency under both saline conditions (50 mM and $100 \mathrm{mM}$ ). Indeed, there is proof that the target fungus bolsters plant tolerance to abiotic stresses in different developmental stages $[25,27]$. Yet the efficiency grade was found to be higher with lower dose (50 $\mathrm{mM}$ ) of $\mathrm{NaCl}$ stressed maize plants than with higher dose (100 mM) (Figure $3 \mathrm{~A}$ and 3B). It is a well-known characteristic of salt stress that salt reduces the Car or $\mathrm{Chl}$ pigments in the photosynthetic apparatus [30]. In this aspect, Figure $3 \mathrm{~A}$ and $3 \mathrm{~B}$ show that T11C seed biopriming reversed the hazardous impact of both $\mathrm{NaCl}$ doses (commonly achieved in nature), consequently allowing protection from reduced photosynthetic efficiency and decrease in the free radical damage potential. Intactness of the Car pigments is reportedly responsible for the suppression of the photo-inhibition of chlorophyll pigments and benefits from increased antioxidant capacity [30]. Some phytohormones triggered by T11C (mainly auxin and its derivatives) might be one of the reasons for this protection in terms of suppressing pigment degradation.

Many studies report that salt stress causes disorganization of ROS scavenging [31-36]. Given the importance of antioxidant enzymes, induction is a protective pathway against the injurious 
effects of ROS, there is a non-enzymatic pathway to modify ROS into less injurious forms within the plant cell [31]. Our enzyme activity data showed no significant increases in SOD, GPX, GR and CAT activities in T11C bioprimed maize plants in the presence of salinity stress both in roots and shoots (Figure 4A, 4B, 4C and 4D). This data is consistent with our previous report, in which we have not determined significant changes in enzyme activity under salt stress by using a different species of this genus [34]. Proline and soluble protein accumulation on the other hand, (osmoregulation by osmoprotectant accumulation in other words) might be the key factor responsible for salt tolerance of the $100 \mathrm{mM} \mathrm{NaCl}$ stressed group that leads to vigorous physiological characteristics observed in T11C bioprimed maize plants shortly before germination.

We have also measured Fv/Fm, NPQ, qPSII, ETR and $\mathrm{qP}$ values, all of which are vital parameters for tracking the effectiveness of photosynthetic capacity. By considering the knowledge that $\mathrm{Fv} / \mathrm{Fm}$ is also a favorable parameter which allows detection of damage and possible photoinhibition of PSII [35], we have deduced that PSII photochemistry (which shows the ratio between $\mathrm{Fv}$ and $\mathrm{Fm}$ ) was much closer to optimum in bioprimed maize plants under $\mathrm{NaCl}$ stress (Figure 5) although no significant difference between lower and higher dose of salt treated groups in terms of $\mathrm{Fv} / \mathrm{Fm}$ ratio was detected. ETR and $\mathrm{qP}$ was also improved greatly under salt stress in T11C-inoculated plants compared to the salt stress only group. On the other hand, since the light harvesting process of pigments occurs depending on each other, any favorable output in a parameter might cause depletion in the output of the other parameters [36], thus the decline detected in the $N P Q$ values might be a result of the increase in the photochemistry of photosynthesis in the T11C inoculated maize plants.

\section{CONCLUSIONS}

In conclusion, seed biopriming with T11C has shown plant growth triggering capacity that improves the root and shoot quality of maize in addition to enhancing resistance to moderate and high salt stress conditions. The use of T11C at the commercial scale may therefore improve crop yields in agricultural applications. With the help of ongoing formulation experiments, we seek to develop cost-effective salt stress relief powder formulas to replace the expensive nitrogen, phosphorus and/or potassium-containing commercial fertilizers which are frequently used in agriculture today.

\section{ACKNOWLEDGEMENTS}

Present work was supported via research funds (project numbers: 2012.102.03.3 and 2015.53001.102.03.07) provided by the Recep Tayyip Erdogan University.

\section{References}

1. M. Pessarakli, I. Szabolcs, Handbook of Plant Crop Stress, NY (1999) USA: CRC Press.

2. Food and Agriculture Organization of the United Nations Save and Grow in practice maize rice wheat. A guide to sustainable cereal production, (2016) Rome.

3. P.M. Hasegawa, R.A. Bressan, J.K. Zhu, H.J. Bohnert, Plant cellular and molecular responses to high salinity. Ann. Rev. Plant Physiol. Plant Mol. Biol., 51 (2000) 463-499.

4. J.K. Zhu, Genetic analysis of plant salt tolerance using arabidopsis, Plant Physiol., 124 (2000) 941-948.

5. V. Fotopoulos, A. Christou, C. Antoniou, G. Manganaris, Hydrogen sulphide: a versatile tool for the regulation of growth and defence responses in horticultural crops, J. Hortic. Sci. Biotechnol., 90 (2015) 227-234.

6. P. Filippou, C. Antoniou, T. Obata, K. Van Der Kelen, V. Harokopos, L. Kanetis, V. Aidinis, F. Van Breusegem, AR. Fernie, V. Fotopoulos, Kresoximmethyl primes Medicago truncatula plants against abiotic stress factors via altered reactive oxygen and nitrogen species signalling leading to downstream transcriptional and metabolic readjustment, J. Exp. Bot., 67 (2016) 1259-1274.

7. A. Sofo, G. Tataranni, A. Scopa, B. Dichio, C. Xiloyannis, Direct effects of Trichoderma harzianum strain T-22 on micropropagated GiSeLa6 (R) (Prunus spp.) rootstocks, Environ. Exp. Bot. 76 (2012) 33-38.

8. R. Hermosa, A. Viterbo, I. Chet, E. Monte, Plantbeneficial effects of Trichoderma and of its genes, Microbiology 158 (2012) 17-25.

9. S.A. Karaoglu, S. Ulker, Isolation, identification and seasonal distribution of soilborne fungi in tea growing areas of Iyidere-Ikizdere vicinity (Rize-Turkey), J. Basic Microbiol., 46 (2006) 208-218.

10. M.S. Goettel, D.G. Inglis Fungi: Hyphomycetes. In: Lacey LA, editor. Manual of techniques in insectpathology, London, UK: Academic Press, (1997) 213-249.

11. F.J. Castillo, Antioxidative protection in the inducible CAM plant Sedum album L. following the imposition of severe water stress and recovery, Oecologia, 107 (1996) 469-477. 
12. D.I. Arnon, Copper Enzymes in Chloroplasts, Polyphenoloxidase in Beta vulgaris, Plant Physiol., 24 (1949) 1-15.

13. E.M.J. Jaspars, Pigmentation of tobacco crowngall tissues cultured in vitro in dependence of the composition of the medium, Physiol. Plant, 18 (1965) 933-940.

14. R.L. Heath, L. Packer, Photoperoxidation in isolated chloroplast, I. Kinetics and stochiometry of fatty acid peroxidation, Arc. Biochem Biophys., 125 (1968) 189198.

15. L.S. Bates, R.P. Waldren, L.D. Teare, Rapid determination of free proline for water-stress studies, Plant Soil, 39 (1973) 205-207.

16. R.S, Dhindsa, W. Matowe, Drought tolerance in two mosses: correlated with enzymatic defence against lipid peroxidation, J. Exp. Bot., 32 (1981) 79-91.

17. H. Urbanek, E. Kuzniak-Gebarowska, K. Herka, Elicitation of defense responses in bean leaves by Botrytis cinerea polygalacturanase, Acta. Physiol. Plant, 13 (1991) 43-50.

18. H. Aebi, Catalase. In: Bergmeyer $\mathrm{H}$, editor. Methods of Enzymatic Analysis. 3rd ed. Weinheim, Germany: Verlag Chemie, (1983) 273-286.

19. C.H. Foyer, B. Halliwell, Presence of glutathione and glutathione reductase in chloroplast: a proposed role in ascorbic acid metabolism, Planta, 133 (1976) 21-25.

20. M.M. Bradford, A rapid and sensitive method for the quantitation of microgram quantities protein utilizing the principle of protein-dye binding, Ann. Biochem., 72 (1976) 248-254.

21. J.N. Miller, J.C. Miller, Statistics and Chemometrics for Analytical Chemistry, Atlanta, Pearson/Prentice USA, 2005.

22. B. Gupta, H. Bingru, Mechanism of salinity tolerance in plants: physiological, biochemical, and molecular characterization, Int. J. Genom., (2014) http://dx.doi. org/10.1155/2014/701596.

23. J. Dluzneiwska, Reaction of fungi of Trichoderma genus to selected abiotic factors, E. J. Polish Agric. Uni. Agro., 6 (2003) 239-242.

24. G.E. Harman, P.K, Kubicek Trichoderma and Gliocladium: Enzymes, biological control and commercial applications, London, UK (1998) Taylor and Francis.

25. H. Bae, R.C. Sicher, M.S. Kim, S.H. Kim, M.D. Strem, RL. Melnick, BA. Bailey, The beneficial endophyte Trichoderma hamatum isolate DIS 219b promotes growth and delays the onset of the drought response in Theobroma cacao, J. Exp. Bot., 60 (2009) 3279-295.
26. T. Benitez, A.M. Rincon, M.C. Limon, A.C. Codon, Biocontrol mechanisms of Trichoderma strains, Int. Microbiol., 7 (2004) 249-260.

27. G.E. Harman, Myths and dogmas of biocontrolchanges in perceptions derived from research on Trichoderma harzianum T-22, Plant Disease, 84 (2000) 377-393.

28. R. Hermosa, L. Botella, M. Montero-Barrientos, A. Alonso-Ramirez, V. Arbona, A. Gomez-Cadenas, C. Nicolas, Biotechnological applications of the gene transfer from the beneficial fungus Trichoderma harzianum to plants, Plant Signal. Behav., 6 (2011) 1235-1236.

29. M. Eisendle, H. Oberegger, R. Buttinger, P. Illmer, $\mathrm{H}$. Haas Biosynthesis and uptake of siderophores is controlled by the PacC-mediated ambient-pH Regulatory system in Aspergillus nidulans, Eukaryot. Cell, 3 (2004) 561-563.

30. R.K. Behera, PC. Mishra, N.K. Choudhary, High irradiance and water stress induced alterations in pigment composition and chloroplast activities of primary wheat leaves, J. Plant Physiol., 159 (2002) 967-973.

31. R. Mittler, Oxidative stress, antioxidants and stress tolerance, Trends in Plant Sci., 7 (2002) 405-410.

32. N. Pehlivan, A.M. Yesilyurt, N. Durmus, S.A. Karaoglu, Trichoderma lixii ID11D seed biopriming mitigates dose dependent salt toxicity in maize, Acta Physiol. Plant., (2017) 10.1007/s1738-017-2375-z.

33. S.E. Ahmed, M.H. Nawata, Y. Domae, T. Sakuratani, Alterations in photosynthesis and some antioxidant enzymatic activities of mungbean subjected to waterlogging, Plant Sci., 163 (2002) 117-123.

34. K. Maxwell, GN. Johnson, Chlorophyll fluorescence-a practical guide, J. Exp. Bot, 51 (2000) 659-668.

35. A.F. Lodeyro, M. Giró, H.O. Poli, G. Bettucci, A. Cortadi, A.M Ferri, N. Carrillo, Suppression of reactive oxygen species accumulation in chloroplasts prevents leaf damage but not growth arrest in salt-stressedtobacco plants. PLoS One, 11 (2016). http://doi.org/10.1371/ journal.pone.0159588

36. F. Moradi, A.M. Ismail, Responses of photosynthesis, chlorophyll fluorescence and ROS-scavenging systems to salt stress during seedling and reproductive stages in rice, Ann Bot., 99 (2007) 1161-1173. 
